\title{
A Study on the Impact of Secondary Market Bench Mark on Mutual Fund Industry
}

* Dr. A Kotishwar

Effulgence

Vol. 14 No. 1

January - June, 2016

Rukmini Devi Institute of Advanced Studies

E-mail : effulgence@rdias.ac.in, Website : www.rdias.ac.in

http://effulgence.rdias.ac.in/user/default.aspx

https://dx.doi.org/10.33601/effulgence.rdias/v14/i1/2016/20-25

\begin{abstract}
Indian mutual fund industry is celebrated golden jubilee year in 2014. Indian stock market performance is measured on par with the global market in spite of less contribution by the Indian investors. The growth of Indian market is mainly contributed by the Indian mutual funds. In this study, it has been examined how benchmarks of equity and debt market impacting the number of schemes and asset under management in India by considering 15 years period that is 2000-2014. Granger causality test has been applied on Johansson co-integration data between benchmarks and the number of schemes and the result unveils that equity schemes were considered by the benchmark, but debt market schemes are not caused by the composite bond index. Regression weight estimation has been applied to measure the influence of benchmark on asset under management and the analysis proved that both the segment under were influenced. By the benchmark fluctuations this study is useful to the investors of mutual funds in India to take inform decision from the investment angle in both segments.
\end{abstract}

Key Words: Secondary Market, Mutual Fund Industry, Equity, Debt, Bench Mark.

\section{INTRODUCTION}

$\mathrm{P}$ erformance evaluation theory stresses the importance of using good benchmarks (Holmstrom, 1979). For example, when determining an airline CEO's bonus, comparing the firm's performance to that of other airlines can improve efficiency by helping to filter out common stocks that are beyond the CEO's control. It would be less efficient to use railroads as the benchmark instead because shocks to the two industries are not perfectly correlated, yet the CEO has an incentive to encourage the use of a railroad benchmark if he believes that airlines are likely to outperform railroads. Of course, the attempt is unlikely to succeed in this setting because a knowledge- able corporate board of directors will realize that railroads are not the best benchmark. The financial services landscape is transforming, with a plethora of changes taking place on the regulatory front. Against this backdrop, asset management companies (AMCs) realise that they need to re-structure their businesses in order to meet the evolving needs of their clients and provide them with complete investment solutions. Although emerging markets such as India provide a wide range of opportunities, it is important to tap into these avenues to fuel the growth of the mutual fund industry.

\section{REVIEW OF LITERATURE}

Berk A. Sensoy (2009) studies almost one-third of actively managed, diversified U.S. equity mutual funds specify a size and value/growth benchmark index in the fund prospectus that does not match the fund's actual style.

Rupeet Kaur (2012) reveals that growth schemes performed better as compared to dividend schemes when evaluate to the benchmark. Whereas the dividend schemes are more volatile as compared to the growth schemes. It is found that only 44 percent growth schemes performed better according to Sharpe, Treynor

* Associate Professor \& HOD, Department of Master of Business Administration, CMR College of Engineering \& Technology, Hyderabad, Telangana 
and Jensen measures. On the basis of R2, the schemes are well diversified which reduced the unsystematic risk. However, the funds are found to be poor in earning better returns either adopting marketing or in selecting underpriced securities.

Shalini Sharma, Arti Gaur and Nancy Arora (2014) evaluate the return with risk associated in the mutual fund and compares the performance of various mutual fund schemes on the basis of benchmark index so as to bring out whether the scheme is outperforming or underperforming the benchmark is measured by using secondary data Sharpe's and Treynor's portfolio performance measure is used to find the risk premium of portfolio relative to the total amount of risk in the portfolio. This reveals that in India almost every sector is likely to witness a huge growth going forward.

Ferreira and Ramos (2009) examined mutual fund industry competition and concentration using a sample of 27 countries. The indicators justified that the mutual fund industry was concentrated universally and some industries offered large fund complexities. Countries higher stock market turnover were connected with low level industry concentration. There was more industry competition in countries with improved quality of institutions and where rules and regulation was more unbolt. Bank concentration and concurrent limitations to slot in new activities in the financial industry tended to decrease firm entry in the mutual fund industry. The launch of new funds was completely associated with simplicity of regulation and negatively linked with industry age. On the whole level of fees tends to be higher in countries with low stock market turnover, where industry size was smaller and where foreign mutual fund companies had a larger market share. Moreover, fund

Deepak Agrawal (2011) in his paper provides an overview of mutual fund activity in India. $\mathrm{He}$ also analyzes data at both the fund manager and fund investor levels. The 26 study revealed that the performance of the Mutual Fund Industry in India is affected by saving and investment habits of the people on one hand and on the second side the confidence and loyalty of the fund manager.

A Kotishwar And P Alekhya (2015) this study has been examine to measure the secondary market movement impact on Mutual inflow and out flow the bi-variable has been apply to measure the relationship of secondary market with mutual fund inflow and out flow granger causality test has been apply to measure the impact of FII and DII flows on mutual funds in flows and out flows and observed that only DII were crossed mutual fund out flow. Both FII and DII flow following to inflows the mutual fund inflow and outflows the analysis for period of 2006 to 2014 so that financial rotation pre and post market movement can be captured.

\section{SCOPE OF THE STUDY}

The study has been emphasized on 15 years data (200014) asset under management of equity and debt has been considered of 46 mutual funds asset management companies from national stock exchange, Equity and debt benchmarks are considered.

\section{OBJECTIVES OF THE STUDY}

1. To measure the correlation between number of schemes with benchmarks and assets under management.

2. To measure the impact of benchmarks of equity and debt on number of schemes.

3. To measure the benchmark impact on asset under management of equity and debt market.

4. To measure the impact of number of schemes on asset under management.

\section{RESEARCH METHODOLOGY}

This research is descriptive in nature and uses the secondary data. Data comprises on 15 years data (200014) asset under management of equity and debt.

Nifty - NSE India

Composite bond index - NSE India

No. of schemes of both debt and equity,

Total assets under management of debt and equity

Pearson bi-variate correlation formula:-

$$
r=\frac{\sum f u v-\frac{\left(\sum f u\right)\left(\sum f v\right)}{n}}{\sqrt{\sum f u^{2}-\frac{\left(\sum f u\right)^{2}}{n}} \times \sqrt{\sum f v^{2}-\frac{\left(\sum f v\right)^{2}}{n}}}
$$

Pearson's correlation coefficient between two variables is defined as the covariance of the two variables divided by the product of their standard deviation. The form of 
the definition involves a "product moment", that is, the mean (the first moment about the origin) of the product of the mean-adjusted random variables; hence the modifier product-moment in the name.

\section{ANOVA Formula:-}

$$
\begin{aligned}
& S S_{\text {total }}=\sum_{j=1}^{p} \sum_{i=1}^{n_{j}}\left(x_{i j}-\bar{x}\right)^{2} \\
& S S_{\text {between }}=\sum_{j=1}^{p} n_{j}\left(x_{j}-\bar{x}\right)^{2} \\
& S S_{\text {within }}=\sum_{j=1}^{p} \sum_{i=1}^{n_{j}}\left(x_{i j}-\bar{x}_{j}\right)^{2}
\end{aligned}
$$

Analysis of variance is a method for decomposing variance in a measured outcome in to variance that can be explained, such as by a regression model or an experimental treatment assignment, and variance which cannot be explained, which is often attributable to random error.

The Granger causality test:

It is a statistical hypothesis test for ascertaining whether one time series can be used for forecasting another time series. It is originally considered that regressions reflect "mere" correlations, but Clive Granger on the other hand argued that causality in economics could be reflected by measuring the ability of predicting the future values of a time series using historical values of another.

$$
\mathbb{P}[Y(t+1) \in A \mid \mathcal{I}(t)] \neq \mathbb{P}\left[Y(t+1) \in A \mid \mathcal{I}_{-X}(t)\right]
$$

Johansen test:

It is used for co integration that allows for more than one co integrating relationship i.e. large data samples. Therefore this test is more generally applicable than the Engle-Granger test which is based on the Dickey-Fuller (or the augmented) test for unit roots.

$$
X_{t}=\mu+\Phi D_{t}+\Pi_{p} X_{t-p}+\cdots+\Pi_{1} X_{t-1}+e_{t}, \quad t=1, \ldots, T
$$

\section{DATA ANALYSIS}

Analysis on correlation between number of schemes with benchmarks and assets under management, impact of benchmarks of equity and debt on number of schemes, benchmark impact on asset under management

\begin{tabular}{|c|c|c|c|c|c|c|c|}
\hline & & EquitySchemes & Nifty & CBI & EquityAUM & DebtAUM & DebtSchemes \\
\hline \multirow[t]{3}{*}{ EquitySchemes } & Pearson Correlation & 1 & $.704^{* *}$ & -0.476 & $.644^{*}$ & $.647^{*}$ & $.801^{* *}$ \\
\hline & Sig. (2-tailed) & & 0.005 & 0.086 & 0.013 & 0.012 & 0.001 \\
\hline & $\mathbf{N}$ & 14 & 14 & 14 & 14 & 14 & 14 \\
\hline \multirow[t]{3}{*}{ Nifty } & Pearson Correlation & $.704^{* *}$ & 1 & $-.856^{* *}$ & $.967^{* *}$ & $.861^{* *}$ & $.886^{* *}$ \\
\hline & Sig. (2-tailed) & 0.005 & & $\mathbf{0}$ & $\mathbf{0}$ & $\mathbf{0}$ & $\mathbf{0}$ \\
\hline & $\mathbf{N}$ & 14 & 14 & 14 & 14 & 14 & 14 \\
\hline \multirow[t]{3}{*}{ CBI } & Pearson Correlation & -0.476 & $-.856^{* *}$ & 1 & $-.878^{* *}$ & $-.616^{*}$ & $-.574^{*}$ \\
\hline & Sig. (2-tailed) & 0.086 & $\mathbf{0}$ & & $\mathbf{0}$ & 0.019 & 0.032 \\
\hline & $\mathbf{N}$ & 14 & 14 & 14 & 14 & 14 & 14 \\
\hline \multirow[t]{3}{*}{ EquityAUM } & Pearson Correlation & $.644^{*}$ & $.967^{* *}$ & $-.878^{* *}$ & 1 & $.837^{* *}$ & $.823^{* *}$ \\
\hline & Sig. (2-tailed) & 0.013 & 0 & $\mathbf{0}$ & & $\mathbf{0}$ & $\mathbf{0}$ \\
\hline & $\mathbf{N}$ & 14 & 14 & 14 & 14 & 14 & 14 \\
\hline \multirow[t]{3}{*}{ DebtAUM } & Pearson Correlation & $.647^{*}$ & $.861^{* *}$ & $-.616^{*}$ & $.837^{* *}$ & 1 & $.901^{* *}$ \\
\hline & Sig. (2-tailed) & 0.012 & $\mathbf{0}$ & 0.019 & $\mathbf{0}$ & & $\mathbf{0}$ \\
\hline & $\mathbf{N}$ & 14 & 14 & 14 & 14 & 14 & 14 \\
\hline \multirow[t]{3}{*}{ DebtSchemes } & Pearson Correlation & $.801^{* *}$ & $.886^{* *}$ & $-.574^{*}$ & $.823^{* *}$ & $.901^{* *}$ & 1 \\
\hline & Sig. (2-tailed) & 0.001 & $\mathbf{0}$ & 0.032 & $\mathbf{0}$ & $\mathbf{0}$ & \\
\hline & $\mathbf{N}$ & 14 & 14 & 14 & 14 & 14 & 14 \\
\hline
\end{tabular}
of equity and debt market and impact of number of schemes on asset under management have been carried out in this section.

Table 1: Correlation between number of schemes with benchmarks and assets under management 
Bi variant correlation has been applied on equity and debt benchmarks, with asset under management and schemes.this result indicates that $\mathrm{CBI}$ is negatively correlated with nifty and equity schemes. Asset under management of debt and schemes were also moderately negatively correlated with that debt benchmark, Equity benchmark is having strong correlation with rest of the variables during the study period.

Table 2: Impact of benchmarks of equity and debt on number of schemes (Co integration test)

\begin{tabular}{|l|l|l|l|l|l|l|l|l|}
\hline LL RANK VALUES & Data Trend: & None & None & Linear & Linear & Quadratic & \\
\hline & Rank or & \multicolumn{2}{l}{ No Interce Intercept } & Intercept & Intercept & Intercept & A IC & SIC \\
\hline & No. of CEs & No Trend & No Trend & No Trend & Trend & Trend & & \\
\hline NIFTY vs. schemes & 0 & -158.266 & -158.266 & -157.503 & -157.503 & -156.328 & 29.50297 & 29.64766 \\
\hline & 1 & -156.058 & -152.194 & -151.534 & -151.127 & -149.989 & 29.82877 & 30.11815 \\
\hline & 2 & -155.907 & -151.505 & -151.505 & -148.686 & -148.686 & 30.52849 & 30.96256 \\
\hline CBI vs. schemes & 0 & -102.695 & -102.695 & -102.594 & -102.594 & -101.493 & 19.39903 & 19.54371 \\
\hline & 1 & -94.6677 & -91.7272 & -91.643 & -90.789 & -89.9615 & 18.66685 & 18.95623 \\
\hline & 2 & -93.5384 & -86.0409 & -86.0409 & -84.3262 & -84.3262 & 19.18881 & 19.62288 \\
\hline
\end{tabular}

Johansson co integration test has been applied between nifty and CBI to number of schemes. The result unveils that log likelihood rank values were in decreasing trend in both non and linear model along with the quadratic AIC and SIC criteria's were also satisfied in all trend models this analysis indicates that data is co integrated between CBI and no. of schemes of equity and debt markets.

Table 3: Granger causality test

\begin{tabular}{|l|r|r|r|}
\hline Null Hypothesis: & Obs & F-Statistic & Prob. \\
\hline EBTSCHEMES does not Granger Cause CBI & 11 & 0.47242 & 0.6449 \\
\hline CBI does not Granger Cause DEBTSCHEMES & & 3.07796 & 0.1203 \\
\hline
\end{tabular}

The granger causality test has been applied to measure the nifty benchmark on number of equity schemes the probability value of granger $0.71>0.5$ indicates that null hypothesis is rejected and accept the alternative hypothesis.Hence this probability depicts that equity schemes were influenced by the equity benchmark.

Table 4: Benchmark impact on asset under management of equity and debt market

\begin{tabular}{|c|c|}
\hline Model Summary & \\
\hline Multiple R & 0.9 \\
\hline R Square & 0.81 \\
\hline Adjusted R Square & 0.775 \\
\hline Std. Error of the Estimate & 0.025 \\
\hline Log-likelihood Function Value & -34.484 \\
\hline
\end{tabular}




\begin{tabular}{|c|c|c|c|c|c|}
\hline & Sum of Squares & Df & Mean Square & F & Sig. \\
\hline Regression & 0.03 & 2 & 0.015 & 23.446 & 0 \\
\hline Residual & 0.007 & 11 & 0.001 & & \\
\hline Total & 0.037 & 13 & & & \\
\hline
\end{tabular}

\begin{tabular}{|c|c|c|c|c|c|c|}
\hline Coefficients & ndardized Coeffi & Standardized Coefficients & & & \\
\hline & B & Std. Error & Beta & Std. Error & T & Sig. \\
\hline (Constant) & 133.796 & 1.622 & & & 82.487 & 0 \\
\hline EquityAuM & 0 & 0 & $\mathbf{- 1 . 2 0 5}$ & 0.234 & -5.152 & 0 \\
\hline DebtAUM & $1.32 \mathrm{E}-05$ & 0 & $\mathbf{0 . 4 0 4}$ & 0.234 & 1.727 & 0.112 \\
\hline
\end{tabular}

Regression weight estimation has been applied to measure the nifty benchmark impact on equity and debt mutual fund assets, the R2 is $95 \%>60$, which indicates that the relation is highly stronger probability value is found to be significant. This analysis indicates that equity benchmark influence is observed on both the segments of mutual fund assets that is equity and debt.

Table 5: The impact of number of schemes on asset under management

\begin{tabular}{|l|l|l|l|l|l|l|l|l|l|}
\hline LL rank values & Rank or & No Intercept & Intercept & Intercept & Intercept & Intercept & & \\
\hline & No. of CEs & No Trend & No Trend & No Trend & Trend & Trend & AIC & SIC \\
\hline & 0 & -212.4936 & -212.494 & -212.489 & -212.489 & -212.404 & 43.29873 & 43.41976 \\
\hline & 1 & -203.9965 & -202.644 & -202.643 & -202.559 & -202.548 & 42.39930 & 42.64137 \\
\hline 2 & -200.3882 & -198.883 & -198.883 & -198.498 & -198.498 & 42.47764 & 42.84074 \\
\hline & & & & & & & & \\
\hline
\end{tabular}

The above analysis of Johansson co integration test has been applied on the stationary data between number of schemes and asset under management of equity and debt market and The result shows that log likelihood rank values were observed in decreasing trend in both linear and quadratic model.log with the alpha level, this indicates that data is co integrated between these two variables.

The above analysis of granger analysis test result unveils that null hypothesis (ho) is rejected because the probability value $0.88>0.5$ and accepts the alternative hypothesis, this test shows that number of schemes of equity and debt are causing the assets under management in mutual fund segment.
FINDINGS OF THE STUDY

1. Debt schemes were strongly correlated with nifty equity schemes. Equity asset under management and debt asset under management but it is negatively correlated with debt benchmark.

2. Equity schemes were caused by the nifty but debt schemes were not caused by the debt benchmark composite index.

3. Equity and debt benchmarks are impacting the asset under management in both the segments.

4. Debt schemes are causing the debt asset under management during the study period. 


\section{CONCLUSION}

The study concludes the analysis of benchmark impact on equity and debt mutual funds. In this study, I had considered composite bond index of NSE as the benchmark for the debt instruments. Nifty has been considered equity benchmark.

Asset under management companies which were approved by the SEBI has been considered to measure the benchmark impact on mutual funds, which indicates that no, of schemes and asset under management of equity and debt market. The analysis had proven that asset under management were impacted by the benchmark. The no. of schemes of equity is affected by the nifty but composite bond index failed to influence the new debt schemes.

Hence there is a scope to do research in this area, by considering various economic factors, which influence the mutual fund asset performance.

\section{REFERENCES}

1) Agrawal, Deepak, (2007) "Measuring Performance of Indian Mutual Funds "Finance India, June 2011. Available at SSRN: http://ssrn.com/abstract $=1311761$

2) Avadhani V.A., "Security Analysis and Portfolio Management”, Himalaya Publishing House, Mumbai, 1997.

3) Berk A. Sensoy (2009) " Performance evaluation and self-designated benchmark indexes in the mutual fund industry " Journal of Financial Economics, 92 (2009) 25-39

4) Bhole L.M. "Financial Institutions and Market Structure, Growth and Innovations”, Tata McGraw Hill Publication, New Delhi, 1995.

5) Ferreira, Miguel A. and Ramos, Sofia Brito (2009), "Mutual Fund Industry Competition and Concentration: International Evidence”. Available at SSRN: http://ssrn.com/abstract $=1343096$ or http://dx.doi.org/10.2139/ssrn.1343096.

6) Kotishwar, A. and P Alekhya (2015) "FII \& DII Fund Flow Impact Of Mutual Funds Inflows And Outflows A Study", Madras University Journal Of Business And Finance, Vol. 3, No. 2, pp. 87-93

7) Rupeet Kaur (2012) "A comparative Analysis Of Growth \& Dividend Tax Oriented Mutual Fund
Schemes In India “, Asia Pac ific Journal of Marketing \& Management Review, Vol.1 (4), December (2012) p g no 26-40.

8) Shalini Sharma Arti Gaur and Nancy Arora (2014) "Mutual Fund Performance Evaluation: A Benchmark Comparison", International Journal of Multidisciplinary Consortium, Volume 1 Issue 1 June 2014, pg 1-10

9) Http://www.moneycontrol.com/

10) Http://www.nse-india.com/

11) Https://www.amfiindia.com/

12) Https://www.valueresearchonline.com/ ads/splash.asp?cid $=1$ 